\title{
Attitudes to illegal behaviour and conservation in western Tanzania
}

\author{
Paulo Wilfred, E. J. Milner-Gulland and Henry Travers
}

\begin{abstract}
Natural resources in and around protected areas in many countries in Africa are under intense pressure as a result of illegal behaviour, such as fishing, hunting and logging. A better understanding of local people's perceptions of the nature of illegal behaviour and the relevance of conservation actions would be useful in informing conservation decisions. We gathered information on the attitudes and perceptions of communities in the vicinity of Ugalla Game Reserve in western Tanzania regarding illegal behaviour and the effectiveness of conservation practices, using household surveys, key informants, and focus groups. We found that local people use the Reserve illegally, especially for hunting (28 \pm SE 6\%) and logging (20 \pm SE 5\%). We explored behaviours that are problematic for conservation in the partially protected areas around Ugalla. Local communities reported feeling isolated, harassed and intimidated by approaches used to protect Ugalla. They were angered by the conservation of Ugalla as a trophy hunting site for foreigners, and the excessive force and beatings used by game rangers to keep them away from the Reserve. Improving local livelihoods (17\%), participatory conservation (16\%), and giving people land for agricultural activities (16\%) were among the ways that local communities felt would reduce illegal activities. Our findings suggest the need for conservation measures to benefit local communities around Ugalla transparently and equitably. Outreach programmes would help to raise conservation awareness and attract positive attitudes towards conservation. To encourage local support for conservation, we also suggest that conservation authorities create and maintain good relations with people living near the Reserve.
\end{abstract}

Keywords Conservation measures, livelihoods, local participation, perceptions, salience, Tanzania, threats to conservation, Ugalla

Supplementary material for this article can be found at https://doi.org/10.1017/So030605317000862

Paulo Wilfred (Corresponding author), Department of Life Sciences, Open University of Tanzania, P.O. Box 23409, Dar es Salaam, Tanzania

E-mail paulo.wilfred@out.ac.tz

E. J. Milner-Gulland and Henry Travers, Department of Zoology, University of Oxford, South Parks Road, Oxford, UK

Received 12 January 2017. Revision requested 24 March 2017.

Accepted 25 May 2017. First published online 5 September 2017.

\section{Introduction}

D rotected areas in Africa are often under pressure from 1 multiple human activities (Taylor \& Dunstone, 1996; Harrison et al., 2015a). This pressure originates both from people living nearby and from those living further away, who can access protected areas directly or in collaboration with local people (e.g. Nyahongo et al., 2009). Conservationists have identified various types of illegal behaviour that, if tackled, would have a significant impact on achieving sustainability in protected areas. Examples include illegal logging (Lawson, 2014) and fishing (Gandiwa et al., 2012), wildlife poaching (Martin \& Caro, 2013), unauthorized settlements, encroachment for agriculture and grazing (Gandiwa et al., 2011), and retaliatory killing of wildlife (Karanth et al., 2012). As demand for natural resources escalates, illegal behaviour can intensify and the need for more focused and productive conservation efforts increases (Igoe \& Croucher, 2007; Brooks et al., 2012).

Many protected areas have been created in areas that were once utilized and controlled by indigenous communities, and thus local livelihood opportunities have been gradually excluded from conservation measures (West et al., 2006). Activities such as subsistence farming, hunting and fishing are actively discouraged in and around protected areas (Brockington \& Wilkie, 2015). Such economic displacements are the root cause of conservation challenges. Local communities receive few tangible benefits from contemporary conservation actions, regardless of the fact that they incur costs from conservation (Brockington, 2006; Brockington \& Wilkie, 2015). Such costs include alienation from natural resources on which their livelihoods depend, human-wildlife conflict, and denial of access to fertile agricultural lands (Salerno et al., 2016). These not only engender negative attitudes towards conservation but can result in accelerated loss of wildlife and habitats (e.g. Prins et al., 2000; Igoe \& Croucher, 2007). Consequently, conservation efforts are now struggling to address livelihood issues (e.g. food insecurity, poverty and unsustainable agricultural practices) and the degradation of natural resources (Agrawal \& Redford, 2006; Brockington \& Wilkie 2015) simultaneously.

Research has a central role to play in any approach aimed at improving conservation strategies (Borgerhoff Mulder et al., 2007). A key research need is to understand the causes of various types of illegal behaviour, and effective measures for controlling them (Bawa et al., 2011; Nuno \& St. John, 2015). Similarly, there is a need to understand people's perceptions of, and attitudes towards, current conservation 
actions, and the factors mediating interactions between local communities and conservation authorities. This is important because illegal actions may be, in part, a response to conservation itself (Ebua et al., 2011; Mutanga et al., 2015; Harrison et al., 2015b). Given the diverse cultural and socioeconomic backgrounds of resource users across various localities, especially in Africa, conservation studies tend to be ecosystem specific (Prins et al., 2000). This is acceptable, as solutions to tackle conservation problems in one ecosystem may not necessarily be valid in another. For example, community development and outreach programmes seem to be effective in developing positive attitudes towards conservation in the Katavi-Rukwa ecosystem of western Tanzania (Borgerhoff Mulder et al., 2007), whereas garnering local support for conservation in the Maasai Steppe in the northern part of the country entails providing incentives conditional on conservation initiatives achieving desired outcomes (Sachedina \& Nelson, 2010).

Since its establishment in 1965, Ugalla Game Reserve (hereafter Ugalla) in western Tanzania has received increasing conservation attention from the Tanzanian government (Fisher, 2002), largely centred on controlling illegal behaviour. Recent studies, however, indicate that the problem of illegal behaviour is escalating (Wilfred \& MacColl, 2014a). Nonetheless, almost nothing is known about the prevalence of illegal behaviour, or the effectiveness and efficiency of conservation measures. To fill this knowledge gap and, most importantly, to inform conservation efforts in western Tanzania, we used the unmatched count technique (Nuno \& St. John, 2015) in combination with household surveys and focus groups to investigate local people's awareness and perceptions of Ugalla and their attitudes towards conservation strategies, the costs and benefits of Ugalla to various resource user groups, and factors influencing the prevalence of, and solutions to, illegal behaviour.

\section{Study area}

Ugalla Game Reserve (c. 5,000 km²; Fig. 1) is surrounded by several partially protected areas (game controlled areas and forest reserves), which act as a buffer zone and constitute a vital component of the Ugalla ecosystem. The main vegetation is miombo woodland, containing valuable timber trees. Ugalla hosts diverse wildlife species, including the wild dog Lycaon pictus, large mammals such as the African elephant Loxodonta africana, and medium and small-sized antelopes such as the sable antelope Hippotragus niger and the impala Aepyceros melampus (Wilfred \& MacColl, 2016). Ugalla is crucial for the connectivity of conservation areas in western Tanzania and is a significant part of the MalagarasiMuyovosi Wetlands Ramsar Site (Kalumanga, 2015), providing habitats for the vulnerable shoebill Balaeniceps rex and wattled crane Bugeranus carunculatus (John, et al.,
2013). Ugalla has a long history of conservation, dating back to the 1920 shen the original occupants of the area (the Wagalla) were evacuated because of an outbreak of sleeping sickness (Fisher, 2002). However, with their centuries-old dependence on Ugalla's natural resources, the people continually forced their way back (Fisher, 2002). As a result, in 1965 the government upgraded the conservation status of Ugalla to Game Reserve to further tighten restrictions on human activities in the area, through Government Notice 281 and 282, June 1965 (Fisher, 2002). The people then resorted to using Ugalla illegally, and illegal behaviour has intensified since 1990 (UGR, 2006; Wilfred \& MacColl, 2014a).

Ugalla is administered by the Wildlife Division of Tanzania through the Ugalla Game Reserve Project, and hosts trophy hunting each year during June-December. Illegal behaviour is deterred by anti-poaching patrols, with intermittent visits carried out by game rangers throughout the year. The project allows local people limited access (by temporary permit) into the Reserve to carry out controlled fishing and beekeeping activities in the dry season, JulyDecember. The aim is to maintain a sense of connection to the Reserve and reduce levels of illegal use (UGR, 2006). Despite these conservation measures, the loss of wildlife and habitat continues to be of great concern (UGR, 2006; Hazelhurst \& Milner, 2007; Wilfred \& MacColl, 2014a).

\section{Methods}

\section{Data collection}

The study was conducted during December 2015-April 2016. We carried out key informant and household interviews and hosted focus group discussions. We selected at random 10 villages from those within $20 \mathrm{~km}$ of the Ugalla boundary for the main study (Fig. 1) and piloted our study in another village, chosen among the villages immediately outside our study zone, based on PW's familiarity with the area. The study zone was defined using village maps obtained from the Ugalla project office and with the help of key informants. Locations were recorded for each village using a global positioning system. At least 50 households were chosen randomly from the village register in each of the study villages, giving a total sample of 541 households. Interviews were conducted with the heads of the households or their representatives, using a structured questionnaire translated into Swahili (the dominant local language in the area). Respondents were assured that the interview would be confidential and anonymous and that they were free to withdraw at any time. If a respondent decided not to participate, the enumerator ended the interview immediately and recorded gender and approximate age. Of the 541 


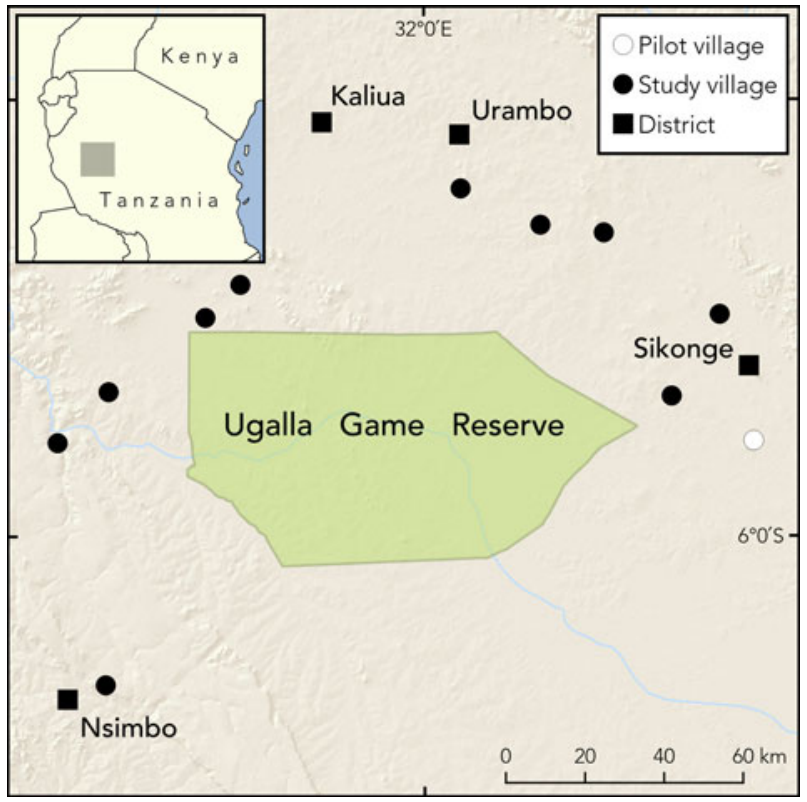

Fig. 1 Location of Ugalla Game Reserve and the study villages in western Tanzania, with approximate locations of districts.

respondents, eight (three women and five men) withdrew from interviews. These were removed from the analysis, leaving a sample size of 533 households.

The aim of the interviews was to gather information about socio-economic characteristics, household wealth local attitudes and perceptions regarding the conservation of Ugalla, and participation in illegal behaviour. Each interview began with questions about gender, age, level of education, household composition, and living standard. Then four unmatched count technique questions (Supplementary Table $\mathrm{S}_{1}$ ) were asked to estimate participation in honey gathering from tree trunks, logging, bushmeat hunting and consumption. These activities were chosen as the main illegal activities in Ugalla, based on PW's experience, the pilot survey, key informants and personal communications with the Ugalla management team. Each participant was asked to answer all four of these questions, but for each question we placed the participant randomly in a control or a treatment group. The control group received a set of non-sensitive items, whereas the treatment group received the same set plus an extra item reflecting the behaviour of interest. The random placement process was performed using a die before approaching the household. This ensured that the respondent was not assigned permanently to the control or treatment groups for all the unmatched count technique questions. Participants in both subsamples were asked how many (not which ones) of the items in the list were true for them. The differences in the means between the treatment group and the control group were used to estimate the prevalence of the sensitive items (types of illegal behaviour). Before answering the unmatched count technique questions, participants were asked a non-sensitive practice question about the type of crops cultivated by the household, to familiarize them with the unmatched count technique process.

We used the basic necessities survey approach to determine household wealth (Supplementary Table S2). A comprehensive list of basic necessities in the study area was developed in collaboration with key informants, tested in the pilot village and refined and improved following discussion in a pilot focus group before it was used in the household surveys. The list contained items that each person in the study village should have and no one should be without. These included common and less common items. Respondents were asked to indicate which of the items were basic necessities and which ones they possessed or had access to. Only the items that were considered to be basic necessities by at least $50 \%$ of the respondents were used to calculate a household wealth score. The overall basic necessities survey score was calculated as the mean of the weightings (proportions) of respondents who said the items were basic necessities, and the actual score was calculated as the mean of the weightings of respondents who possessed or had access to the items.

A card with pictures of faces representing various feelings was used to help respondents to express their feelings about local living standards, Ugalla and conservation. The faces were scored on a scale of -2 (very bad or very sad) to 2 (very good or very glad). Open-ended attitudinal questions were asked to elicit free answers about illegal behaviour and suitable approaches to achieving effective management that could remedy the limitations of the current Ugalla management practices (Supplementary Material 1).

We triangulated our household surveys with focus group discussions in six randomly selected study villages, hosting two focus groups on the same day in each village, with 4-6 participants in each. Participants were divided into male and female groups to put them at ease, promote participation and ensure a relaxed environment for discussions. There was at most a 20-minute interval between the focus groups to prevent groups influencing each other's responses. The discussions captured information about illegal behaviour and possible solutions. Seasonality of types of illegal behaviour was determined by asking participants to populate a monthly activities calendar with items that represented illegal behaviour. Other non-sensitive items, such as the cultivation of tobacco and food crops, and the rainfall pattern, were also included in the calendar.

\section{Data analysis}

The unmatched count technique responses were analysed using linear mixed effect models in the lmes package (Bates et al., 2015) in $R$ v. 3.2.2 (R Development Core Team, 2015) following Nuno et al. (2013). Behaviour 
prevalence estimates were derived by modelling separately the responses given for each question against a predictor variable representing whether respondents had received the control or treatment card, with a village grouping factor included in all models (see Supplementary Tables S3-S6 for model summaries). Model selection was conducted by comparing Akaike information criterion values corrected for small sample sizes (AICc) for prospective models, and the most parsimonious model was selected except in cases in which $\triangle$ AICc was $>4$. Model residuals were checked for normality and correlation with the treatment predictor, with no issues detected.

Responses to open-ended questions from focus groups and household surveys were indexed using hierarchical coding. The main codes (principal responses to the questions) and their respective content subcodes (short descriptions of the contents of the principal responses) were developed. These codes were used to calculate relative response frequencies. We used $\chi^{2}$ tests to analyse categorical variables from the questions related to attitudes and perceptions regarding conservation. Salience analysis (Papworth et al., 2013) was performed for free-listing questions as follows:

$$
\text { salience }=\frac{1+\text { length }_{i}-\text { position }_{i}}{\text { length }_{i}},
$$

where position is how soon the item was mentioned by the group and length is the total number of behaviour types or solutions identified by focus group $i$. Then the cultural salience $(S)$ was calculated as follows:

$$
S=\frac{\sum_{\text {salience }_{i}}}{n}
$$

where $\mathrm{n}$ is the number of focus groups. Cultural salience was o-1 (o, the item was not important; 1 , the item was most important and was mentioned first in each focus group).

\section{Results}

\section{Attitudes towards Ugalla}

When asked whether they would be glad or sad if Ugalla were abolished, $>45 \%$ of respondents said they would be sad, compared to $26 \%$ who would be glad. Relatively better off individuals (with higher basic necessities survey scores) were more likely to say they would be sad (one-way ANOVA, $F_{2,497}=3.655, P=0.0266$; Supplementary Fig. S1). Thirty-six percent of respondents said the Reserve was not managed effectively and $21 \%$ said it was managed effectively. Those who thought Ugalla was managed ineffectively were more likely to say they would be glad if it were abolished $\left(\chi^{2}=60.36, \mathrm{df}=4, \mathrm{P}<0.0001\right.$; Fig. 2$)$. Ten of 12 focus groups reported that they would be sad if Ugalla were abolished, but none of the groups were in favour of the approaches used to conserve it. People who said they would feel sad if Ugalla were abolished mostly referred to it as the only source of essential natural resources (Supplementary Table S7). Reasons for people not being happy with the management of the Reserve included not receiving any benefits from the Reserve, and lack of active local involvement in conservation and use of natural resources therein.

\section{Perceived costs and benefits of Ugalla}

Fifty-four percent of respondents perceived they incurred at least one type of cost from Ugalla, and 51\% perceived at least one benefit. Common costs included restrictions on resource use, frequent conflicts with resource management authorities, and not having enough land for agricultural activities and settlements because of the Reserve (Supplementary Table S8). The most commonly perceived benefits were availability of honey, and the Reserve as a location for logging, hunting and fishing activities. Group discussions and the unmatched count technique suggested that local communities obtained these benefits predominantly through unauthorized/illegal subsistence use of the Reserve.

When asked to rank various groups of people they thought benefited or lost from Ugalla, significantly more survey respondents felt that foreign nationals benefited most, compared to Tanzanian people and villages both near and far from the Reserve $\left(\chi^{2}=620.47, \mathrm{df}=6\right.$, $\mathrm{P}<0.0001$; Fig. 3). This was supported by the focus groups: nine of the 12 groups felt that Ugalla benefited mostly foreign nationals, and the remainder thought that foreigners benefited moderately from the Reserve. Most respondents complained about foreign nationals being given hunting rights and the freedom to use resources as they wished (Supplementary Table S9). In a group discussion conducted in a village near the Reserve, participants appeared to be angry at foreign hunters:

Ugalla does not benefit us at all, we just see or hear vehicles going back and forth in dry seasons, when large numbers of animals are shot by strangers.

Hunting companies normally fool us by hiring two or three youths from the village for activities like skinning, building base camps, cooking and cleaning to make us believe that they are good people.

Tanzanian people in general were another group who were considered to benefit most from the Reserve. People were aware that the Reserve was owned by the government and that the country benefits through trophy hunting fees. Half of the focus groups perceived that Ugalla benefited Tanzania as a country more than local people.

Feelings about who benefits or bears costs from Ugalla seemed to influence respondents' attitudes towards the Reserve. Those who felt that people close to the Reserve benefited were more likely to feel sad about abolishing Ugalla than those who felt that people far from the Reserve benefited 


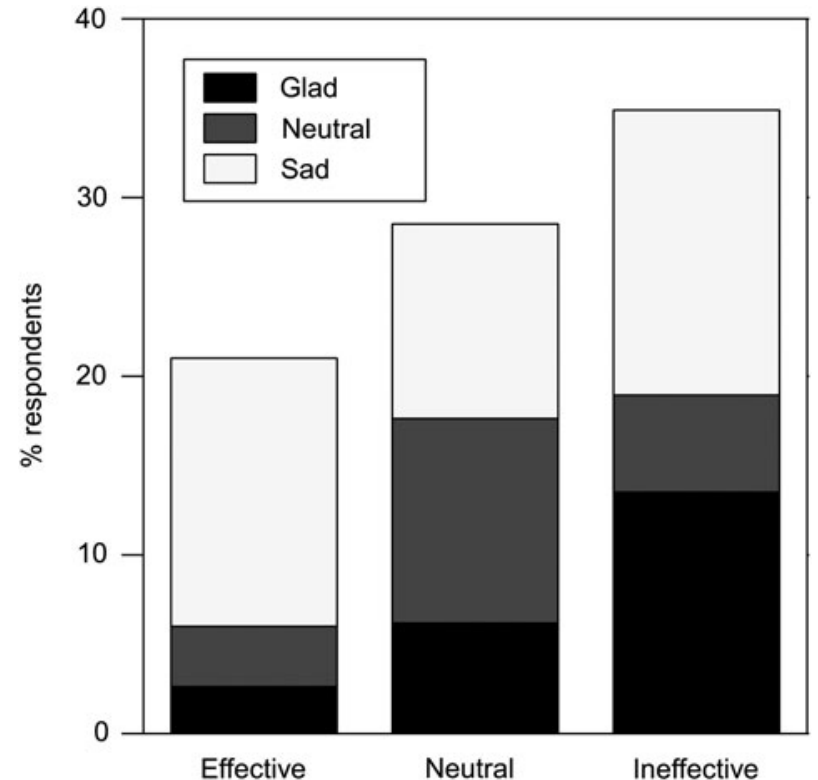

FIG. 2 Percentage of respondents $(n=533)$ who said they would be glad, neutral, or sad if Ugalla Game Reserve (Fig. 1) were abolished, in each of three categories of perception regarding whether the Reserve was managed effectively.

$\left(\chi^{2}=13.0, \quad \mathrm{df}=4, \quad \mathrm{P}=0.0112 ;\right.$ Supplementary Fig. S2 $)$. Similarly, respondents who felt that foreigners benefited were more likely to feel sad about abolishing Ugalla than those who felt Tanzanians benefited $\left(\chi^{2}=9.45, \mathrm{df}=2\right.$, $\mathrm{P}=0.0088$; Fig. S3). Also, those who felt that people living near the Reserve and Tanzanians lost or benefited moderately were more likely to think that Ugalla was not managed effectively $\left(\chi^{2}=26.62, \mathrm{df}=4, \mathrm{P}<0.001 ; \chi^{2}=10.67, \mathrm{df}=4\right.$, $\mathrm{P}=0.0306$; Supplementary Figs $\mathrm{S}_{4} \& \mathrm{~S}_{5}$, respectively). People were generally more in favour of their livelihoods and well-being being acknowledged and catered for by conservation measures than having Ugalla abolished (Supplementary Table S7).

\section{Illegal behaviour threatening Ugalla}

Wildlife poaching and logging were the most common activities in our study area according to the unmatched count technique data, with $28 \pm$ SE $6 \%$ of respondents having hunted bushmeat and $20 \pm$ SE $5 \%$ having logged illegally in Ugalla in the previous 12 months. $22 \pm \mathrm{SE} 7 \%$ had consumed bushmeat and $18 \pm$ SE $6 \%$ gathered honey. Hunting and logging were also the illegal activities most commonly cited in the survey and by focus groups (Table 1). Although they were ranked lower as illegal activities by focus groups, fishing, extensive tobacco farming, and setting of forest fires were reported to be among the types of behaviour that were problematic for conservation. Increased demand for land and extensive grazing in areas near the Reserve were ranked third and fourth, respectively, in the

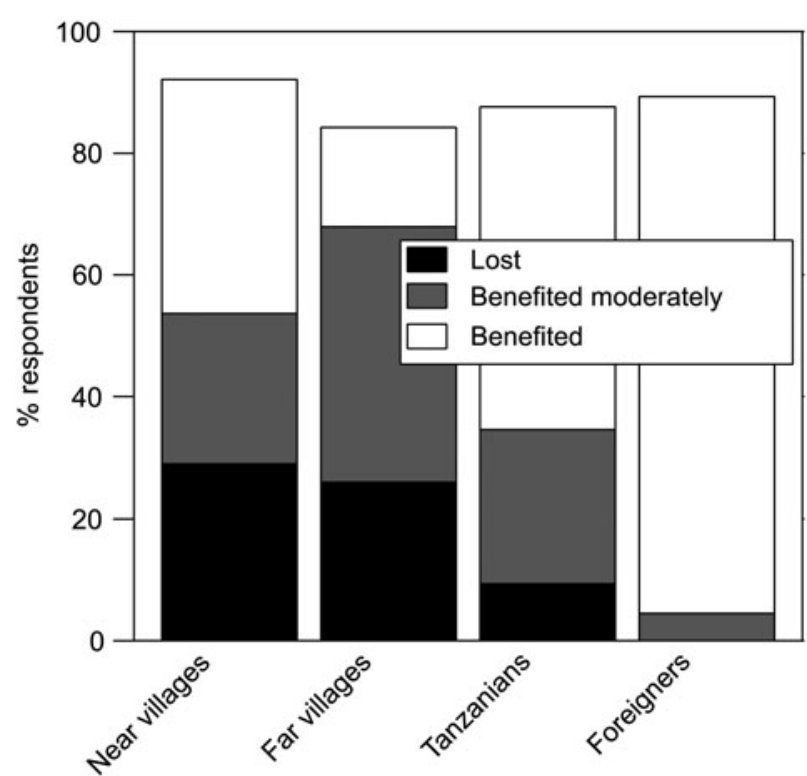

FIG. 3 Percentage of respondents $(n=533)$ who perceived various groups of users (villages near the Reserve, villages far from the Reserve, Tanzanian people in general, and foreign nationals) benefited, benefited moderately or lost from Ugalla Game Reserve (Fig. 1).

focus group discussions. The conservation status of partially protected areas was also of considerable concern to focus groups (Supplementary Table S7); for instance, one focus group participant complained that

Migratory pastoralists, who also practise extensive farming, have invaded partially protected areas and other forests near Ugalla. In most cases, they are let into these areas by corrupt local forest officers who accept bribes from these pastoralists. They keep cattle in large herds, and then forests are being cleared on large scales to create space for grazing and farming. As a result, our beekeeping activities are affected, rain is scarce and unpredictable, and you can hardly find wild animals here.

Higher levels of poaching and logging in the Reserve were also attributed partly to scarcity of wildlife and forest resources in partially protected areas; for example, abolishing Ugalla was considered to be a bad idea by respondents during the household survey because 'the Reserve was the only area with animals' (Supplementary Table $\mathrm{S}_{7}$ ).

The seasonal calendar (Supplementary Plate $\mathrm{S}_{1}$ ) elicited other threats to Ugalla related to mismatches between agricultural activities and some of the common types of illegal behaviour, especially fishing, logging and hunting (Supplementary Fig S6). This suggests people depend on natural resources as an alternative source of livelihood at certain times of year. The peak harvesting period for tobacco (the main commercial crop) and common food crops is February-May (wet season). Most of the dry season (August-October) is a slack period, when people have little to do, and this coincides with the period when, according to focus groups, bicycles and sometimes lorries are seen 
TABLE 1 Frequency of illegal activities in and around Ugalla Game Reserve, Tanzania (Fig. 1), as identified by survey respondents $(\mathrm{n}=533)$, and their salience score as ranked by 12 focus groups. Blank cells indicate no data.

\begin{tabular}{lll}
\hline & $\begin{array}{l}\text { Frequency (\% of } \\
\text { respondents) }\end{array}$ & $\begin{array}{l}\text { Salience } \\
\text { score }\end{array}$ \\
\hline Poaching $^{1,2}$ & 40.0 & 0.45 \\
Logging $^{1,2}$ & 38.7 & 0.50 \\
Forest fires $^{2}$ & 12.8 & 0.09 \\
Fishing $^{1,2}$ & 11.0 & 0.05 \\
Tobacco farming $^{2}$ & 9.6 & 0.04 \\
Grazing $^{2}$ & 8.4 & 0.15 \\
Charcoal extraction $^{2}$ & 8.4 & \\
Honey collecting $^{1,2}$ & 8.4 & 0.06 \\
Poverty \& increasing village $^{\text {population }}$ & 7.5 & 0.07 \\
Farming $^{2}$ & & \\
Poor relations between $^{\text {people \& Reserve }}$ & 7.3 & 0.02 \\
People dislike Reserve $^{\text {Ad hoc settlements }}{ }^{2}$ & 5.0 & \\
Debarking of trees $^{1,2}$ & & 0.02 \\
Increased demand for land $^{2}$ & 4.5 & 0.03 \\
Trophy hunting $^{1,2}$ & 3.4 & \\
Corruption by forest officers $^{2}$ & 3.0 & 0.19 \\
\hline
\end{tabular}

${ }^{1}$ Conducted within Ugalla Game Reserve

${ }^{2}$ Conducted in the partially protected areas immediately adjacent to Ugalla Game Reserve

frequently fetching cut timber out of Ugalla. In the early months of the dry season (June-August) food is abundant, and people can generate incomes from the sale of tobacco and food crops such as rice, groundnuts, maize and cassava. During September-March, food stocks accumulated in the preceding harvesting months are usually depleted, and food prices are higher because of increased demand, intensifying local dependence on wildlife and other forest resources.

All focus groups reported that during periods of reduced agricultural yields the main source of livelihood is natural resources. Illegal logging and hunting are conducted throughout the year. Bushmeat hunting is somewhat more prevalent than logging during the rainy season, and viceversa during the dry season. Illegal fishing is seasonal, occurring in particular during June-November, when water levels in the rivers within Ugalla drop and catches increase. Honey collecting is concentrated in a short transition period between the rainy and dry seasons, during May and June.

\section{Solutions to illegal behaviour}

The top six potential solutions to illegal behaviour expressed by survey respondents also ranked high in the focus group discussions, each with $S>0.1$ (Table 2). Improving local livelihoods had the highest frequency in the survey, confirming the importance of Ugalla as a source of livelihood
TABLE 2 Frequency of potential solutions to illegal behaviour in and around Ugalla Game Reserve, Tanzania (Fig. 1), as identified by respondents $(n=533)$, and their silence score as ranked by 12 focus groups. Blank cells indicate no data.

\begin{tabular}{|c|c|c|}
\hline Solution & $\begin{array}{l}\text { Frequency (\% of } \\
\text { respondents) }\end{array}$ & $\begin{array}{l}\text { Salience } \\
\text { score }\end{array}$ \\
\hline Improve livelihoods & 17.3 & 0.11 \\
\hline $\begin{array}{l}\text { Give land outside Reserve back } \\
\text { to village }\end{array}$ & 16.1 & 0.35 \\
\hline $\begin{array}{l}\text { Active participation of local } \\
\text { people }\end{array}$ & 16.0 & 0.13 \\
\hline Law enforcement & 15.2 & 0.27 \\
\hline Conservation education & 15.2 & 0.14 \\
\hline $\begin{array}{l}\text { Good relations between rangers } \\
\text { \& local people }\end{array}$ & 11.6 & 0.54 \\
\hline Settle boundary disputes & 11.3 & \\
\hline $\begin{array}{l}\text { Stop harassing \& intimidating } \\
\text { local people }\end{array}$ & 5.4 & 0.08 \\
\hline $\begin{array}{l}\text { Allow controlled subsistence } \\
\text { hunting \& logging within } \\
\text { Reserve }\end{array}$ & 5.1 & 0.08 \\
\hline $\begin{array}{l}\text { Reconciliation between local } \\
\text { people \& authorities }\end{array}$ & 4.0 & \\
\hline $\begin{array}{l}\text { Deal with illegal forest } \\
\text { encroachments }\end{array}$ & 3.4 & \\
\hline Allow free access into Reserve & 2.8 & \\
\hline Build a fence around Reserve & 1.7 & \\
\hline Entrepreneurship education & & 0.08 \\
\hline Alternative building materials & & 0.06 \\
\hline $\begin{array}{l}\text { Involve ex-poachers in } \\
\text { anti-poaching }\end{array}$ & & 0.03 \\
\hline
\end{tabular}

support, and corroborating qualitative statements made in the focus groups and survey responses (Supplementary Table $\mathrm{S}_{7}$ ). Livelihood improvement was frequently associated with the need for more land for agricultural production. During focus group discussions there were complaints that Ugalla and the partially protected areas covered large areas, leaving local people with limited land for agricultural activities. The need to ensure good relations between game rangers and local people was ranked first in the focus groups $(S=0.54)$, and was mentioned by $12 \%$ of survey respondents. This echoes the responses to the question regarding why Ugalla was managed ineffectively, which indicated illfeeling towards game rangers among study participants (Supplementary Table $S_{7}$ ). Other important options for tackling illegal behaviour included promoting people's participation in conservation activities, law enforcement and conservation education.

\section{Discussion}

The escalating pressures exerted on protected areas, and limited resources to address exploitation of natural resources are compelling conservationists to promote better 
understanding, consideration and inclusion of the views of local people in conservation efforts (Allendorf, 2007; Andrade \& Rhodes, 2012; Karanth \& Nepal, 2012). Here we assessed the use, role and management of Ugalla Game Reserve from the perspective of local people. We found that the majority of local people were happy with the Reserve but not with the management approaches used to protect it. The main reason for the positive attitude towards Ugalla is that the Reserve is an important source of livelihoods (e.g. fishing, beekeeping, logging and hunting; Supplementary Table $S_{7}$ ), although by illegal means, as evidenced by the findings from the unmatched count technique. Respondents disliked the mostly isolative management approaches in Ugalla particularly because they did not realize tangible benefits from such conservation efforts, and because there were tense relations between local people and conservation authorities. The perception that conservation activities benefit mostly foreign nationals further indicates that limited local participation in conservation efforts is a salient concern. A similar study by Karanth \& Nepal (2012) investigating local attitudes and perceptions regarding protected areas in India and Nepal had similar findings, and a similar situation exists in many other areas where conservation fails to engage with local people (e.g. Harrison et al., 2015a).

There was a strong perception that Ugalla is protected only as a trophy hunting site for foreigners, and the resultant benefits do not trickle down to the affected communities. Similar experiences elsewhere in Africa suggest that trophy hunting schemes offer little or no benefit for those affected by protected areas and their management (Economists at Large, 2013; Bamford et al., 2014). Key informants noted that trophy hunting is a source of substantial foreign income for Tanzania, and priority is given to foreign hunters who can pay high prices. This top-down approach is normally justified by the assumption that local communities will realize the conservation value of trophy hunting, and comply (Wilfred, 2012). However, our findings suggest that the topdown conservation approach may have propagated conflicts between local people and conservation authorities (e.g. both interview respondents and focus groups complained about the use of excessive force and beatings by game rangers).

Law enforcement is the dominant approach in Ugalla to ensure adherence to conservation rules. Game rangers carry out anti-poaching patrols to deter illegal behaviour and other activities that threaten the Reserve (UGR, 2006). However, we found that most of these activities are still continuing, with high levels of illegal use of forest and wildlife resources. Another issue identified by the focus groups was that the surrounding partially protected areas are under increasingly severe pressure from local and migratory agropastoralists, affecting wildlife and their habitat. Wildlife is so scarce in the partially protected areas that subsistence hunters are unlikely to catch anything there (Wilfred \&
MacColl, 2014b). It seems likely, therefore, that the degradation of natural resources in the partially protected areas is contributing to conservation pressure on Ugalla. Partially protected areas act as buffers between protected areas and local communities, and therefore they should receive their due share of conservation attention (e.g. Bamford et al., 2014). Participatory conservation activities commonly take place in partially protected areas or buffer zones (Paudel et al., 2007), but efforts to achieve their objectives and make conservation a competitive form of land use cannot be successful in degraded areas (Robinson et al., 2013). We suspect that one of the reasons illegal use of natural resources is a problem in Ugalla is that there has been no effective participatory conservation in the partially protected areas. Elsewhere, for example around Bwindi Impenetrable National Park, Uganda, a range of participatory conservation initiatives are in place (Harrison et al., 2015a). Such initiatives have the potential to bring tangible conservation benefits to local communities, thereby reducing exploitation of natural resources (Andrade \& Rhodes, 2012). Our finding that livelihood enhancement was strongly recommended as the best option for tackling conservation challenges in Ugalla supports findings of other studies (Coad et al., 2008; Moshi, 2016). Respondents frequently mentioned giving land in the partially protected areas back to local people for agricultural activities as one of the solutions to illegal behaviour. Elsewhere, it is not uncommon for local people to demand access to protected area land, as agriculture is an important source of livelihoods in rural areas (Kumssa \& Bekele, 2014).

Overall, our findings indicate that for successful protection of Ugalla, conservation activities need to be improved, taking careful account of local attitudes and perceptions. We suggest initiating and promoting outreach programmes to help raise awareness and engender positive attitudes towards conservation. Ugalla could benefit from knowledge of what is being done elsewhere in western Tanzania (e.g. Borgerhoff Mulder et al., 2007). As people's livelihoods are dependent on natural resources, the importance of participatory conservation initiatives that aim to strike a fair balance between meeting conservation needs and improving living standards cannot be overstated. This has potential to provide benefits for both partially protected areas and local communities. The partially protected areas must be managed effectively to guarantee sustainable use of natural resources.

Local participation in conservation is considered to be one of the most important measures for ensuring the longterm sustainability of protected areas (West et al., 2006). In Tanzania the contemporary approach to participatory conservation is the establishment of wildlife management areas (Kiwango et al., 2015). These are areas of community land in which local people have usage rights over the wildlife resources. They are usually created in partially protected areas, with the aims of benefiting local people and reducing 
pressure on protected and partially protected areas (IRA, 2007). There are two wildlife management areas in our study area, Ipole and Uyumbu, in Sikonge and Urambo Districts, respectively. Focus groups and our personal observations indicated that each of these covers a relatively small area and comprises $c$. four member villages. They began as pilot projects (alongside others elsewhere in Tanzania) more than a decade ago. Like other wildlife management areas in the country (e.g. Igoe \& Croucher, 2007), Uyumbu and Ipole are facing a number of challenges, including lack of equitable sharing of benefits, poor funding, poor local capacity building, and over-exploitation of natural resources (Nelson, 2007). It is therefore not surprising that respondents felt isolated from conservation activities in Ugalla. Future work should consider assessing the nature, extent and constraints of participatory conservation, and put forth recommendations on how to improve communitybased conservation in this area.

Agricultural expansion may lead to a trade-off between conservation and livelihoods, but further studies should also examine the household-level livelihoods and conservation significance of subsistence agriculture and how agricultural practices can be made more sustainable and environmentally friendly (e.g. Scherr \& McNeely, 2008; Munthali et al., 2012). Study participants were not against retaining Ugalla as a protected area but were against game rangers using unreasonable force in their activities. Good relations between conservation authorities and local people, transparency in conservation activities, and the fair and equitable sharing of benefits arising from the use of Ugalla are central to addressing threats to Ugalla.

'The future of wildlife in Africa rests in the hands of its indigenous people...' (Hurt \& Ravn, 2000, p. 304), and local communities can be crucial sources of knowledge that can complement professional knowledge to ensure effective conservation of natural resources (Khan \& Bhagwat, 2010; Gandiwa et al., 2014). Using focus group discussions, key informants and household interviews we were able to gain insights about local attitudes and perceptions regarding Ugalla, the distribution of its conservation benefits, illegal behaviour, and the way forward for better conservation. Our findings from this mixed-method approach represent a basis for effective conservation interventions in Ugalla. However, further work is needed to investigate how conservation efforts can be reformed. This should lead to local conservation authorities experiencing less resistance in implementing conservation decisions, and to conservation interventions targeting the issues that matter most for those affected by protected areas.

\section{Acknowledgements}

This study was conducted as part of PW's Commonwealth Academic Fellowship at the University of Oxford, UK. The
Rufford Small Grants Foundation supported the fieldwork. We are grateful to Urambo, Kaliua, Sikonge (Tabora Region) and Nsimbo (Katavi Region) districts for permissions to conduct research in rural areas; to members of the Interdisciplinary Centre for Conservation Science at Oxford University for their useful advice and comments before, during and after the fieldwork; to Eugen George M., Paul Sosthenes, Philipo Ngure, Sadat Omary M., and Frederic Sunday for research assistance; and to two anonymous reviewers for their helpful and constructive comments. This study adhered to the ethical standards of the University of Oxford and the Open University of Tanzania. We received official approval locally at regional, district and village levels. The lead author (PW) is Tanzanian, and therefore these permissions were adequate for research conducted in the rural communities living adjacent to protected areas. We further sought and received the consent of our research participants.

\section{Author contributions}

PW designed and implemented the study and wrote the article. EJMG and HT provided guidance on study design and analysis and edited the article. HT also carried out some of the statistical analysis.

\section{References}

Agrawal, A. \& Redford, K.H. (2006) Poverty, Development, and Biodiversity Conservation: Shooting in the Dark? Working Paper No. 26. Wildlife Conservation Society, New York, USA.

Allendorf, T.D. (2007) Residents' attitudes toward three protected areas in southwestern Nepal. Biodiversity and Conservation, 16, 2087, http://dx.doi.org/10.1007/s10531-006-9092-Z.

Andrade, G.S.M. \& Rhodes, J.R. (2012) Protected areas and local communities: an inevitable partnership toward successful conservation strategies? Ecology and Society, 17, 14, http://dx.doi.org/ 10.5751/ES-05216-170414.

Bamford, A.J., Ferrol-Schulte, D. \& Wathan, J. (2014) Human and wildlife usage of a protected area buffer zone in an area of high immigration. Oryx, 48, 504-513.

Bates, D., Maechler, M., Bolker, B. \& Walker, S. (2015) Fitting linear mixed-effects models using lme4. Journal of Statistical Software, 67, 1-48.

BawA, K.S., RaI, N.D. \& Sodhi, N.S. (2011) Rights, governance, and conservation of biological diversity. Conservation Biology, 25, 639641.

Borgerhoff Mulder, M., Caro, T.M. \& Msago, O.A. (2007) The role of research in evaluating conservation strategies in Tanzania: the case of the Katavi-Rukwa ecosystem. Conservation Biology, 21, $647-658$.

Brockington, D. (2006) The politics and ethnography of environmentalisms in Tanzania. African Affairs, 105, 97-116.

Brockington, D. \& Wilkie, D. (2015) Protected areas and poverty. Philosophical Transactions of the Royal Society B, 370, http://dx.doi. org/10.1098/rstb.2014.0271.

Brooks, J.S., Waylen, K.A. \& Borgerhoff Mulder, M. (2012) How national context, project design, and local community 
characteristics influence success in community-based conservation projects. Proceedings of the National Academy of Sciences of the United States of America, 109, 21265-21270.

Coad, L., Campbell, A., Miles, L. \& Humphries, K. (2008) The Costs and Benefits of Protected Areas for Local Livelihoods: A Review of the Current Literature. Working Paper. UNEP World Conservation Monitoring Centre, Cambridge, UK.

Eвua, V.B., Agwafo, T.E. \& Fonkwo, S.N. (2011) Attitudes and perceptions as threats to wildlife conservation in the Bakossi area, South West Cameroon. International Journal of Biodiversity and Conservation, 3, 631-636

Economists at Large (2013) The \$20o Million Question: How Much Does Trophy Hunting Really Contribute to African Communities? A report for the African Lion Coalition, prepared by Economists at Large, Melbourne, Australia.

Fisher, E. (2002) Forced resettlement, rural livelihoods and wildlife conservation along the Ugalla River in Tanzania. In Conservation and Mobile Indigenous Peoples: Displacement, Forced Settlement, and Sustainable Development (eds D. Chatty \& M. Colchester), pp. 142-157. Berghahn Books, New York, USA.

Gandiwa, E., Zisadza-Gandiwa, P., Muboko, N., Libombo, E., Mashapa, C. \& GwaZani, R. (2014) Local people's knowledge and perceptions of wildlife conservation in southeastern Zimbabwe. Journal of Environmental Protection, 5, 475-481.

Gandiwa, E., Zisadza-Gandiwa, P., Mutandwa, M. \& Sandram, S. (2012) An assessment of illegal fishing in Gonarezhou National Park, Zimbabwe. E3 Journal of Environmental Research and Management, 3, 0142-0145.

Gandiwa, P., Matsvayi, W., NGwenya, M.M. \& Gandiwa, E. (2011) Assessment of livestock and human settlement encroachment into the northern Gonarezhou National Park, Zimbabwe. Journal of Sustainable Development in Africa, 13, 19-33.

Harrison, M., Baker, J., Twinamatsiko, M. \& Milner-Gulland, E.J. (2015a) Profiling unauthorized natural resource users for better targeting of conservation interventions. Conservation Biology, 29, $1636-1646$.

Harrison, M., Roe, D., Baker, J., Mwedde, G., Travers, H., Plumptre, A. et al. (2015b) Wildlife Crime: A Review of the Evidence on Drivers and Impacts in Uganda. International Institute for Environment and Development, London, UK.

Hazelhurst, S. \& Milner, D. (2007). Watershed Assessment of the Ugalla Landscape. USDA Forest Service Technical Assistance Trip report. Http://www.rmportal.net/library/content/usda-forest-service/ africa/USFS_Watershed_Assessment_of_the_Ugalla_Landscape.pdf/ view [accessed 15 June 2012].

Hurt, R. \& Ravn, P. (2000) Hunting and its benefits: an overview of hunting in Africa with special reference to Tanzania. In Wildlife Conservation by Sustainable Use (eds H.H.T. Prins, J.

G. Grootenhuis \& T.T. Dolan), pp. 295-313. Kluwer Academic Publishers, Dordrecht, The Netherlands.

Igoe, J. \& Croucher, B. (2007) Conservation, commerce, and communities: the story of community-based wildlife management areas in Tanzania's northern tourist circuit. Conservation \& Society, $5,534-561$

IRA (Institute of Resource Assessment) (2007) Assessment and Evaluation of the Wildlife Management Areas in Tanzania. Wildlife Division, Ministry of Natural Resources and Tourism, Dar es Salaam, Tanzania.

John, J.R.M., Nahonyo, C.L., Lee, W.S. \& Msuya, C.A. (2013) Observations on nesting of shoebill Balaeniceps rex and wattled crane Bugeranus carunculatus in Malagarasi wetlands, western Tanzania. African Journal of Ecology, 51, 184-187.
Kalumanga, E. (2015) How elephants utilize a miombo-wetland ecosystem in Ugalla landscape, Western Tanzania. $\mathrm{PhD}$ thesis. Stockholm University, Stockholm, Sweden.

Karanth, K.K., Gopalaswamy, A.M., DeFries, R. \& Ballal, N. (2012) Assessing patterns of human-wildlife conflicts and compensation around a central Indian protected area. PLOS ONE, 7 (12), e50433.

Karanth, K.K. \& Nepal, S.K. (2012) Local residents' perception of benefits and losses from protected areas in India and Nepal. Environmental Management, 49, 372-386.

Khan, M.S. \& Bhagwat, S.A. (2010) Protected areas: a resource or constraint for local people? Mountain Research and Development, 30, 14-24.

Kiwango, W.A., Komakech, H.C., Tarimo, T.M.C. \& Martz, L. (2015) Decentralized environmental governance: a reflection on its role in shaping wildlife management areas in Tanzania. Tropical Conservation Science, 8, 1080-1097.

Kumssa, T. \& Bekele, A. (2014) Attitude and perceptions of local residents toward the protected area of Abijata-Shalla Lakes National Park (ASLNP), Ethiopia. Journal of Ecosystem \& Ecography, 4, 138, http://dx.doi.org/10.4172/2157-7625.1000138.

Lawson, S. (2014) Illegal Logging in the Democratic Republic of Congo. Energy, Environment, and Resources report (EER PP 2014/03). Chatham House, London, UK.

Martin, A. \& Caro, T. (2013) Illegal hunting in the Katavi-Rukwa ecosystem. African Journal of Ecology, 51, 172-175.

Moshi, B.S. (2016) Impacts of protected areas on local livelihood: a case study of Saadani National Park. MSc thesis. Norwegian University of Science and Technology, Trondheim, Norway.

Munthali, S.M., Mkandawire, R.M. \& Tembo, N. (2012) Sustainable agriculture - a panacea for achieving biodiversity conservation and rural development in Sub-Saharan Africa? In Rural Development: Contemporary Issues and Practices (ed. R. S. Adisa). InTech. Http://dx.doi.org/10.5772/29004 [accessed 1 November 2016].

Mutanga, C.N., Vengesayi, S., Muboko, N. \& Gandiwa, E. (2015) Towards harmonious conservation relationships: a framework for understanding protected area staff-local community relationships in developing countries. Journal for Nature Conservation, 25, 8-16.

Nelson, F. (2007) Emergent or Illusory? Community Wildlife Management in Tanzania. International Institute for Environment and Development, London, UK.

Nuno, A., Bunnefeld, N., Naiman, L.C. \& Milner-Gulland, E.J. (2013) A novel approach to assessing the prevalence and drivers of illegal bushmeat hunting in the Serengeti. Conservation Biology, 27, 1355-1365.

Nuno, A. \& S T. John, F.A.V. (2015) How to ask sensitive questions in conservation: a review of specialized questioning techniques. Biological Conservation, 189, 5-15.

Nyahongo, J.W., Holmern, T., Kaltenborn, B.P. \& Røskaft, E. (2009) Spatial and temporal variation in meat and fish consumption among people in the western Serengeti, Tanzania: the importance of migratory herbivores. Oryx, 43, 258-266.

Papworth, S., Milner-Gulland, E.J. \& Slocombe, K. (2013) The natural place to begin: the ethnoprimatology of the Waorani. American Journal of Primatology, 75, 1117-1128.

Paudel, N.S., Budhathoki, P. \& Sharma, U.R. (2007) Buffer zones: new frontiers for participatory conservation? Journal of Forest and Livelihood, 6, 44-53.

Prins, H.H.T., Grootenhuis, J.G. \& Dolan, T.T. (eds) (2000) Wildlife Conservation by Sustainable Use. Kluwer Academic Publishers, Dordrecht, The Netherlands. 
R Development Core Team (2015) R: A Language and Environment for Statistical Computing. R Foundation for Statistical Computing, Vienna, Austria. Https://www.R-project.org/ [accessed 8 June 2016].

Robinson, E.J.Z., Albers, H.J. \& Busby, G.M. (2013) The impact of buffer zone size and management on illegal extraction, park protection, and enforcement. Ecological Economics, 92, 96-103.

Sachedina, H. \& Nelson, F. (2010) Protected areas and community incentives in savannah ecosystems: a case study of Tanzania's Maasai Steppe. Oryx, 44, 390-398.

Salerno, J., Borgerhoff Mulder, M., Grote, M.N., Ghiselli, M. \& PACKeR, C. (2016) Household livelihoods and conflict with wildlife in community-based conservation areas across northern Tanzania. Oryx, 50, 702-712.

Scherr, S.J. \& McNeely, J.A. (2008) Biodiversity conservation and agricultural sustainability: towards a new paradigm of 'ecoagriculture' landscapes. Philosophical Transactions of the Royal Society B, 363, 477-494.

TAylor, J.V. \& Dunstone, N. (eds) (1996) The Exploitation of Mammal Populations. Chapman \& Hall, London, UK.

UGR (Ugalla Game Reserve) (2006) A Checklist of Plants, Animals and Birds in Ugalla Game Reserve. Unpublished report. Ugalla Game Reserve Project, Tabora, Tanzania.

West, P., Igoe, J. \& Brockington, D. (2006) Parks and peoples: the social impact of protected areas. The Annual Review of Anthropology, 35, 251-277.
Wilfred, P. (2012) Patterns of wildlife exploitation in the Ugalla ecosystem of western Tanzania. PhD thesis. University of Nottingham, Nottingham, UK.

Wilfred, P. \& MacColl, A.D.C. (2014a) The pattern of poaching signs in Ugalla Game Reserve, western Tanzania. African Journal of Ecology, 52, 543-551.

Wilfred, P. \& MacColl, A.D.C. (2014b) Legal subsistence hunting trends in the Ugalla ecosystem of western Tanzania. European Journal of Wildlife Research, 60, 371-376.

Wilfred, P. \& MacColl, A.D.C. (2016) Status of wildlife at trophy hunting sites in the Ugalla Game Reserve of western Tanzania. Tropical Conservation Science, 9, 1-10.

\section{Biographical sketches}

PaUlo WilfRed's research focuses on wildlife conservation in western Tanzania. He has a strong interest in conservation implications of wildlife utilization. E.J. Milner-Gulland is Tasso Leventis Professor of Biodiversity at Oxford University, with broad interests in the design and evaluation of conservation interventions (http:// www.iccs.org.uk). Henry Travers's research focuses on understanding the effectiveness and impact of conservation interventions. 